\title{
Socio-economic Evaluation of the Warrantage Mechanism in North Benin (West Africa): Case of the Maize and Rice Producers
}

\author{
Comlan Hervé Sossou ${ }^{1} \&$ Victor Codjo ${ }^{2}$ \\ ${ }^{1}$ Agricultural Policy Analysis Program, National Institute of Agricultural Research, Benin \\ ${ }^{2}$ School of Rural Economy, AgroEconomics and Management, National University of agriculture, Benin \\ Correspondence: Victor Codjo, School of Rural Economy, AgroEconomics and Management, National \\ University of agriculture, 02 BP 2110, Cotonou, Benin. Tel: 229-9649-2185. E-mail: codjovictor@gmail.com
}

Received: March 3, 2020

doi:10.5539/jas.v12n5p167

\author{
Accepted: April 4, 2020 \\ Online Published: April 15, 2020 \\ URL: https://doi.org/10.5539/jas.v12n5p167
}

\begin{abstract}
Warrantage is a type of proximity stock associated with a widely used credit system. It is a financing system that allows farmers to deposit their harvesting products in a warehouse managed by a farmer organization to receive a loan from a financial institution in return. The objective of this study is to carry out a socio-economic evaluation of the warrantage mechanism in northern Benin. Data were collected using questionnaires and interview guides from a sample of 94 rice and maize producers. The perception of the profitability of the warrantage transaction was analyzed using the Pearson chi-square homogeneity test, while the economic evaluation of this profitability was done using the profit margin calculation. The analysis of the strengths, weaknesses, potentialities and obstacles of the producer-level warrantage mechanism has been done through Kendall's W-rank test. This study revealed that warrantage operation generated a high and positive profit margin for maize and rice crops. The study also revealed that the sale at a remunerative price, the good conservation of the stocks and the obtaining of credits constitute its strengths. The delay in setting up the credit granted and the unavailability of products for the treatment of stored products were weaknesses. The existence of micro-finance structures and the availability of producers to participate in the process have been the potentialities of the warrantage operation while the inexistence of market for the sale of stored products and the lack of adequate warehouses for storage constitute these obstacles. For a perfect success of this operation, it was hoped a more offensive awareness of beneficiaries and a timely start of the operation by the rapid introduction of credit to mobilize more producers.
\end{abstract}

Keywords: warrantage, socioeconomic assessment, profitability, success, failure, potential and obstacles

\section{Introduction}

Insufficient credit Figures prominently among the many constraints that hamper the intensification of agricultural activities among small producers in sub-Saharan Africa in general and in particular in Benin (Lothoré, 2010; Egah, 2014). Indeed, family farms are often excluded from the banking system because they present a significant level of risk: production dependent on weather conditions, highly variable profitability, seasonal credit needs, savings that are difficult to mobilize (Madulu, 2011; Bouchitté et al., 2012). At the same time, these farmers are asking for standard credits: consumption, production, marketing operations, equipment, etc. to which microfinance institutions cannot always respond. Apart from the constraints linked to the farmers themselves, the inadequacy of the requested guarantee (insufficient personal contribution, blocked savings up to $20 \%$ of the credit, or joint guarantees) and the weakness of the portfolios reduce the capacity of these institutions to respond at the request of credit from a large number of weak producers (Fraval, 2000). Thus, to finance their agricultural inputs (fertilizers, seeds, etc.) at the start of the season, small producers often use the traditional credit system granted by traders on usurious terms and whose repayment is most often made, in kind, with the harvest estimated as low as possible (AFDI, 2007; Pender et al., 2008). Consequently, to meet their cash flow needs to meet basic needs, small producers are forced to sell a good part of their production, often just after harvest, agriculture is generally their only source of income. The simultaneous influx of agricultural products into the market, combined with the rigidity of demand, leads to lower prices and therefore low agricultural incomes (Attahirou, 2007). This situation keeps producers in a vicious circle where the very poorly remunerative nature of the productions leads to reduced possibilities of intensification of these productions or diversification of the sources of income and vice versa weak (Lothoré, 2010). Small producers are thus kept in a situation of 
food insecurity, especially during the so-called "lean" period, when cereal stocks are depleted while new crops are still awaited. In this context, a warrantage system was introduced and implemented in Benin to facilitate the rural population access to credits based on inputs or to loans for income generating activities (Tabo et al., 2006). It is a financing system allowing farmers to deposit their products in a secure warehouse to receive in return a loan from a financial institution (Coulter et al., 2009). Agricultural warrantage consists for a peasant organization and/or its members, in obtaining a loan by guaranteeing their productions (soybeans, sorghum, rice, corn, peanuts, etc.) likely to increase in value. The producer therefore offers his harvest as collateral for repayment of the loan requested to finance agricultural production or any other activity. This system involves several types of actors such as farmers' organizations, microfinance institutions, input suppliers and warehouses (Antonaci et al., 2013). The warrantage appears as a means of access to credit for a few months and whose guarantee is a stock of agricultural products liquidable by the bank in the event of default of the warrant. It also allows producers to have access to credit while keeping their products, and the microfinance institution to increase credit security. Is warrantage financially profitable for maize and rice producers? How do they perceive this profitability? What are these successes, failures, potentials and obstacles?

The objective of this study is to carry out the socio-economic evaluation of the warrantage mechanism in North Benin at the level of maize and rice producers.

\section{Warrantage Mechanism}

Warrantage, also called storage credit or warranteed credit, is a technical rural credit system of short-term credit, adapted to the financing needs and the guarantee capacities of a certain socio-professional category, guaranteed by a stock of agricultural products "Warrantables" (conservable, not very bulky and likely to increase in value) stored in an appropriate store. The peasant organization or individual producer is then called a warrant. The main objective of the warrantage system is to prevent small producers from selling off their food production immediately after harvesting, by offering them the possibility of accessing credit (Attahirou, 2007; Coulter et al., 2009). The warrantage, also called storage credit or warrantee credit, is a rural credit system of a few months whose guarantee is a stock of product liquidable by the bank in the event of default (the warrant). It consists, for a farmer organization and/or its producer members, in obtaining a loan by guaranteeing their production (soybeans, sorghum, rice, corn, peanuts, etc.) likely to increase in value. The actors involved in the process seem to have a very precise understanding of the warrantage mechanism implemented in the departments concerned (Vermeylen, 2007).

Credit warrantage, also called storage credit, is a rural credit system which consists, for a peasant organization (PO) and/or its producer members, to obtain a loan by guaranteeing their production (millet, sorghum, rice, corn, peanut etc.) likely to increase in value (FAO, 2011). The farmer can thus access a credit allowing him to meet his obligations at harvest, and keep his production for periods of price ceilings (Augères, 2007; Attahirou, 2007; Coulter et al., 2009). Warrantage systems have two main objectives: to prevent small producers from selling just after the lean season (period which separates the end of consumption from the harvest of the previous year and the depletion of granary reserves from the following harvest, during which the population is forced to manage to find monetary resources in order to buy food) when prices are at their lowest and give them the possibility of accessing credit. In a context where debt remains the lot of small farmers, warrantage credit is offered as a response to better access to financial services for them. In addition to being a cash management tool, the warrantage system can also be an agricultural risk management tool (Gouillat, 2014).

Warrantage involves several actors. Depending on the context, a participant in the system can occupy several positions, or on the contrary work with subcontractors. The Figure 1 show step by step the main stakeholders who are the following concerned in the warrantage mechanism. There are:

- Producer: he seeks to store his production, obtain credit and sell his production during the lean season.

- Warehouser: he stores the products after having carried out the necessary treatments (washing, sorting, etc.) guaranteeing their quality. Its role is to record the entries and exits of the stock and to issue the receipt, called "warrant", which certifies the type of product stored, the quantity, the date, etc.

- Issuer of the loans: a bank or an MFI (microfinance institution) agrees to recognize the guarantee based on the receipts and issues a loan to the producer on the basis of this guarantee. The loan thus allows the producer to continue to provide for his family without directly selling his production at low prices (Vermeylen, 2007; FAO, 2010a). 
Step 1: at harvest

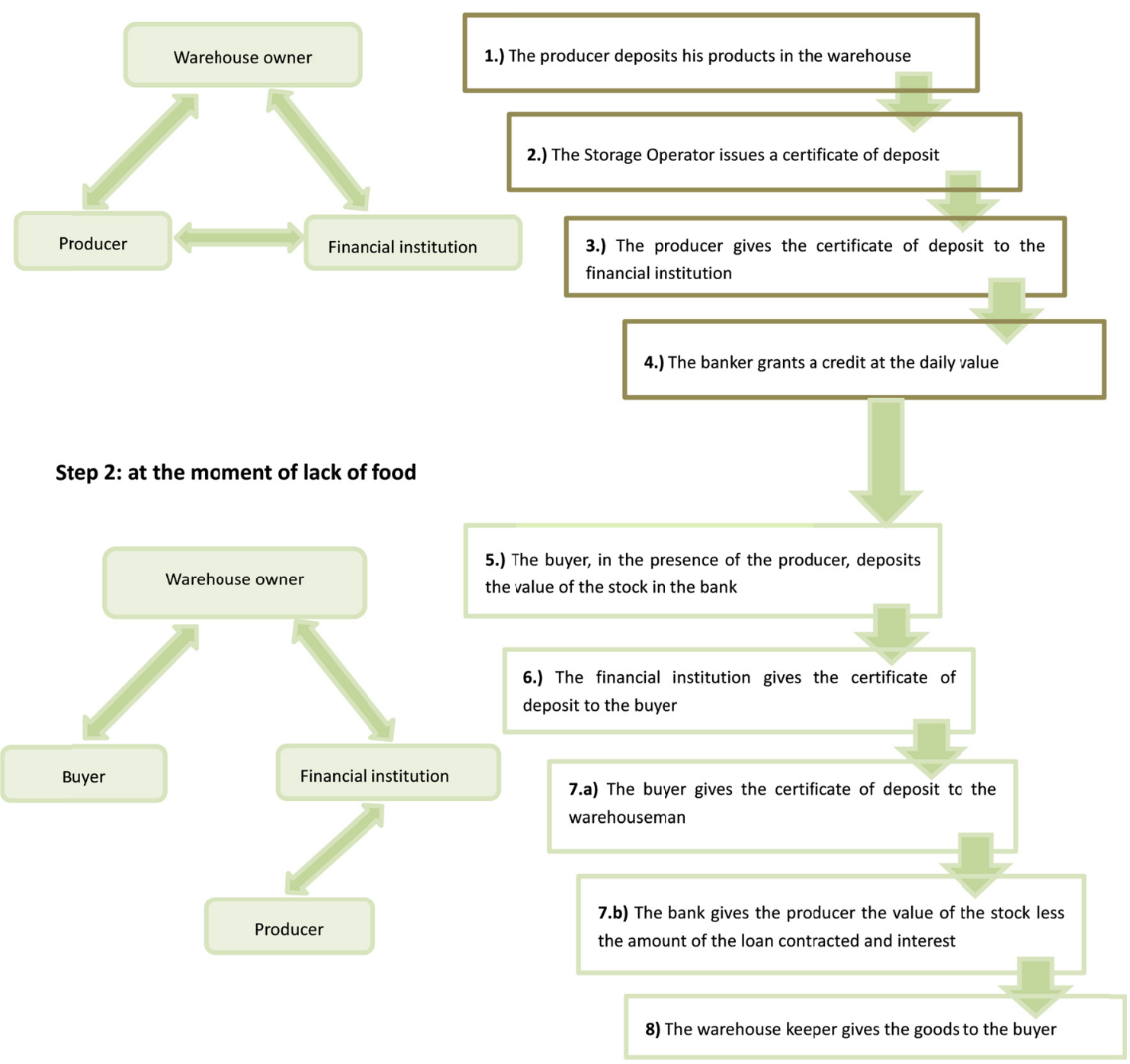

Figure 1. Step by-step operation of a simple warrantage

During the step 2, the producer stores at harvest time when prices are relatively low by obtaining credit to be able to carry out an income generating activity. At the moment of the lack of food, he destocks and reimburses the loan through the sale of production and keeps the margin of generated by income generating activities and by the intra-annual price increase (Coulter et al., 2009).

\section{Materials and Methods}

\subsection{Study Area}

The present study was carried out in North Benin more precisely in the departments of Atacora, Borgou and Alibori. Indeed, these departments more precisely the municipalities namely N'Dali, Bembèrèkè, Malanville, Kandi, Toucountouna and Ouassa-Péhunco had housed the pilot phase of the implementation of the warrantage system as part of the partnership agreement relating to the implementation of the Agricultural Diversification Support Project by Regional Action Centers for Rural Development of Borgou-Alibori provides below component 3.2 of the "Coordination of value chains and financing" component. The actions carried out relate in particular to the establishment of a multi-stakeholder framework, the upgrading of storage stores, the training of stakeholders involved in the actual storage operations, the setting up of credits and the monitoring of collections. 


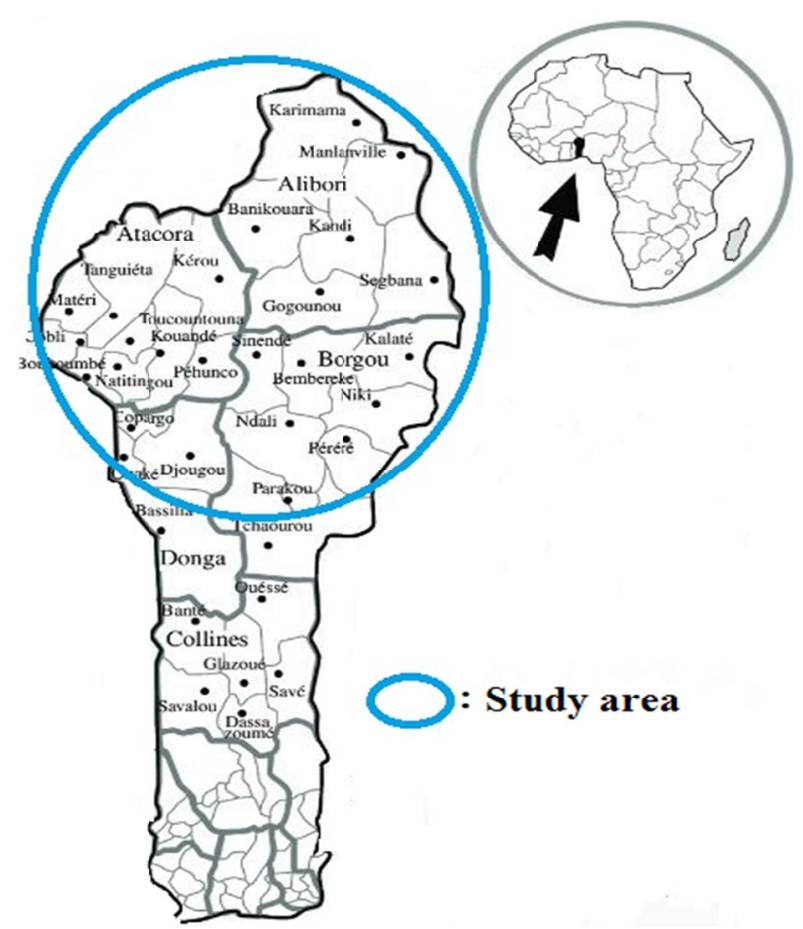

Figure 2. Map of the study area

\subsection{Sampling}

The villages chosen were selected on the basis of a reasoned sampling from the list of villages benefiting from the warrantage. In total, all the fourteen villages concerned were visited for the collection of individual information. However, for the group interviews, a random choice made it possible to select one village per commune.

As for the observation units for the quantitative surveys, they were established through a random sampling by village from the exhaustive list of producers who benefited from the warrantage. For a more objective comparison, producers informed of the operation but who did not take part in it were surveyed to also take into account their perceptions as observers with regard to the choice of participating producers and other aspects. The survey villages being known, the minimum size of the sample of producers to be surveyed was determined by Yamane's formula (1967):

$$
\mathrm{n}=\frac{\mathrm{N}}{1+\mathrm{N}(\mathrm{e})^{2}}
$$

Where, $\mathrm{n}=$ the sample size, $\mathrm{N}=$ the total of the interest's population and $\mathrm{e}=$ the margin of error fixed at $5 \%$.

With $\mathrm{N}=125$ maize and rice producers, the Yamane's formula was used to calculate the sample size. In total, a sample of 94 maize and rice producers was drawn. Maize and rice crops were chosen because there were the main crops which were used in the activity of warrantage.

The spatial distribution of the sample in the municipalities is presented in Table 1. It presents the distribution of the sample according to the zones and the types of producers.

Table 1. Distribution of samples according to departments

\begin{tabular}{|c|c|c|c|c|}
\hline \multirow{2}{*}{ Departments } & & \multicolumn{2}{|c|}{ Producers categories } & \multirow{2}{*}{ Total } \\
\hline & & Warehousers & No warehousers & \\
\hline \multirow{2}{*}{ Borgou and Alibori } & Effective & 27 & 19 & 46 \\
\hline & Percentage (\%) & 60 & 40 & 100 \\
\hline \multirow{2}{*}{ Atacora } & Effective & 25 & 23 & 48 \\
\hline & Percentage (\%) & 51 & 49 & 100 \\
\hline \multirow{2}{*}{ Total } & Effective & 52 & 42 & 94 \\
\hline & Percentage $(\%)$ & 55.30 & 44.70 & 100 \\
\hline
\end{tabular}




\section{Methods of Data Collection and Analysis}

\subsection{Qualitative and Quantitative Data Collection}

Qualitative data was collected through two types of interviews: focus-groups with management committees for warehouses storing warranted products, and individual interviews with institutional stakeholders. Specific guides have been developed for each category of actors. The quantitative data was collected from producers benefiting from the warrantage operation through individual surveys using a questionnaire. The constitutive elements of the questionnaire are the perceptions on the organizational device of the operation, the interest rate practiced, the amounts granted, the periods of establishment of the credits, the maturities of recovery, the duration of the credit, the cost of the operation, the MFIs selected, the structures involved, etc.

\subsection{Analytical Framework}

The evaluation have adopted a mixed data collection method and the analysis of this data were done according to the nature of data. Qualitative data was subjected to thematic content analysis. The main technique used is qualitative document analysis which is adequate when dealing with a large amount of unstructured data. The qualitative analysis of the document favored the understanding of internal structures, the creation of typologies, the identification of associations, the search for explanations, and the development of new ideas, theories or strategies. Descriptive statistics and non-parametric tests were used to analysis the qualitative data. These tests were done by using the SPSS 23 software.

\subsubsection{Analysis of the Perception of the Profitability of the Warrantage Activity}

The analysis of the perception of the profitability of the warrantage activity was made by means of the Pearson chi-square homogeneity test. Indeed, fishermen have spoken out on indicators (very profitable, profitable and unprofitable) to give their perceptions of the profitability of the warrantage operation. A contingency table with counting data was produced for each department (Borgou/Alibori and Atacora) according to the indicators. Pearson's chi-square consistency test was applied to the contingency table to analyze changes in perceptions across departments. For this purpose, there would be a variation between the perceptions of producers according to their department if the probability associated with the chi-square homogeneity test is less than or equal to $10 \%$. The calculation of the Pearson chi-square coefficient values and its probability were done by using the software R 3.3.3.

\subsubsection{Evaluation of the Profitability of the Warrantage Activity}

The evaluation of the profitability of the warrantage activity is made on the basis of quantitative data collected at the level of the process management committees. The cost elements relating to the implementation of the operation such as the preparation and packaging costs of the products (cleaning, sorting and grading), handling costs (packaging/unpacking, loading/unloading), transport costs (from the field to the house, from the house to the store or to the market), losses (physical losses, dehydration of products), storage costs, investment costs (interest linked to a loan to bank or equity), commissions, fees and informal payments will be completed. All of these data made it possible to calculate the profit margin by crop, which represents the gain or profit derived from the implementation of the warrantage mechanism. The profit margin is the difference between turnover (turnover) and direct costs or total costs (TC). Turnover is the product of the quantity sold and the unit selling price. The calculation of this profit margin was made using Microsoft Excel 2016.

\subsubsection{Analysis of Successes, Failures, Potentials and Obstacles of the Warrantage Mechanism}

The analysis of the successes, failures, potentialities and obstacles of the warrantage mechanism at the producer level was made using the Kendall rank test $\mathrm{W}$. The different producer rankings made it possible to determine the average rank. To calculate $\mathrm{W}$, the sum of the ranks $\mathrm{Rj}$ was determined in each column of the table $\mathrm{k} \cdot \mathrm{N}$. Then, the $\mathrm{Rj}$ were summed and then divided by $\mathrm{N}$ to obtain the average value of $\mathrm{Rj}$. Finally, the deviations between each $\mathrm{Rj}$ and the mean value were calculated and the sum of the squares of these deviations "s" was obtained:

$$
\mathrm{W}=\frac{\mathrm{s}}{1 / 12 \cdot \mathrm{k}^{2}\left(\mathrm{~N}^{3}-\mathrm{N}\right)}(\text { Kendall, 1955) }
$$

Where, $\mathrm{k}$ : number of series of arrangements, number of judges, that is to say the number of producers of corn or rice; N: number of successes, failures, potentials and obstacles and $1 / 12 \cdot \mathrm{k}^{2}\left(\mathrm{~N}^{3}-\mathrm{N}\right)$ : the sum "s" which would be obtained in the case of a perfect agreement between the $\mathrm{k}$ rankings.

$$
\mathrm{s}=\sum\left(\mathrm{Rj}-\frac{\sum \mathrm{Rj}}{\mathrm{N}}\right)^{2}
$$

Where, $\mathrm{s}=$ sum of the squares of the deviations between the $\mathrm{Rj}$ observed and the mean of these $\mathrm{Rj}$. 
SPSS 23 software was used to calculate the coefficient W and determine the average ranks of successes, failures, potentialities and obstacles of the warrantage mechanism at producer level. The classification obtained will be statistically validated if the Kendall coefficient $\mathrm{W}$ is different from zero, the Chi-square value is high and the probability (asymptotic meaning) is less than or equal to $10 \%$. Success, failure, potentiality or obstacle is more considered if its average rank is lower. This method has been used by (Codjo et al., 2018).

\section{Results}

\subsection{Sociodemographic and Economic Characteristics of Producers}

\subsubsection{Sociodemographic Characteristics of Producers}

Table 2 presents the socio-demographic characteristics of the respondents according to the area of intervention. The table shows that gender, education and literacy, contact with microfinance institutions and membership in a producer organization vary as well depending on the study areas. Overall, the rate of male producers is $78.70 \%$. Women, however, represent $21.30 \%$ for all of the producers surveyed. The table revealed that not all producers are generally educated. Producer contacts with Microfinance Institutions and membership in a producer organization do not vary significantly from one area to another.

Table 2. Sociodemographic characteristics of producers

\begin{tabular}{llll}
\hline Variables & & Borgou and Alibori (\%) & Atacora (\%) \\
\hline \multirow{2}{*}{ Sex } & Male & 71.10 & 85.70 \\
& Female & 28.90 & 14.30 \\
\multirow{2}{*}{ Educational level } & No & 62.20 & 42.90 \\
& Primary & 24.40 & 38.80 \\
& Secondary & 11.10 & 14.30 \\
& University & 2.20 & 4.10 \\
Literacy level & No & 62.20 & 43.80 \\
& Learn & 2.20 & 2.10 \\
\hline Contact with IMF & Learn and write & 35.60 & 54.20 \\
\hline Membership of a producer organization & 60.50 & 55.30 \\
\hline
\end{tabular}

\subsubsection{Socio-economic Characteristics of Producers}

The main occupations of producers overall are agriculture and trade (Table 3). The latter reveals that participating producers are more involved in these occupations than non-participating producers. These two main occupations are followed by livestock and crafts at the level of participating producers while at the level of non-participating producers, it is livestock and crafts that compete. Based on the rank index of agriculture (very high compared to other indices) at the level of all producers, we deduce that they mainly engage in agriculture as their main occupation. Furthermore, the high level of this rank index among the participating producers makes it possible to conclude that agriculture as the main occupation is decisive in participating in the warrantage process. Indeed, agriculture allows the producer to guarantee the availability of the product to be warranted. It therefore plays a vital role in it.

Table 3. Main occupations of producers

\begin{tabular}{|c|c|c|c|c|}
\hline \multirow{2}{*}{ Main occupation } & \multicolumn{2}{|c|}{ Warehousers } & \multicolumn{2}{|c|}{ No warehousers } \\
\hline & Average rank index & Rank order & Average rank index & Rank order \\
\hline Agriculture & 49.33 & 1 & 41.67 & 1 \\
\hline Trade & 11.67 & 2 & 4.33 & 2 \\
\hline Breeding & 4 & 4 & 2.67 & 3 \\
\hline Arts and crafts & 5.67 & 3 & 2.67 & 4 \\
\hline Civil service & 1.33 & 6 & 2 & 5 \\
\hline Worker & 1.67 & 5 & 0.67 & 6 \\
\hline entrepreneurship & 1.33 & 7 & - & - \\
\hline Fishery & - & - & 0.67 & 7 \\
\hline
\end{tabular}




\subsection{Perception of the Profitability of the Warrantage Operation}

The appreciation of the profitability of the warrantage mechanism is measured on the basis of the perceptions of the producers surveyed The $\mathrm{x}^{2}$ homogeneity test carried out on the contingency table relating to the perceptions of the profitability of the warrantage operation reveals a highly significant independence $(p<0.001)$. Overall, the operation was found to be profitable and even very profitable for most of the producers interviewed (Figure 3). In fact, an average of $40 \%$ of producers considered overall that warrantage was profitable against $40 \%$ who said it was more. In contrast, $5 \%$ of Atacora producers said the mechanism is not profitable. This statement could be explained by the upheavals and dysfunctions observed at the level of certain management committees. Sometimes the type of management noted at the level of certain microfinance structures was a factor limiting the profitability of the operation. In the Borgou and Alibori departments, almost all of the producers surveyed recognized the profitability of the operation. $60 \%$ felt that the warrantage was even very profitable. In all cases, the various commitments were respected by all the actors.

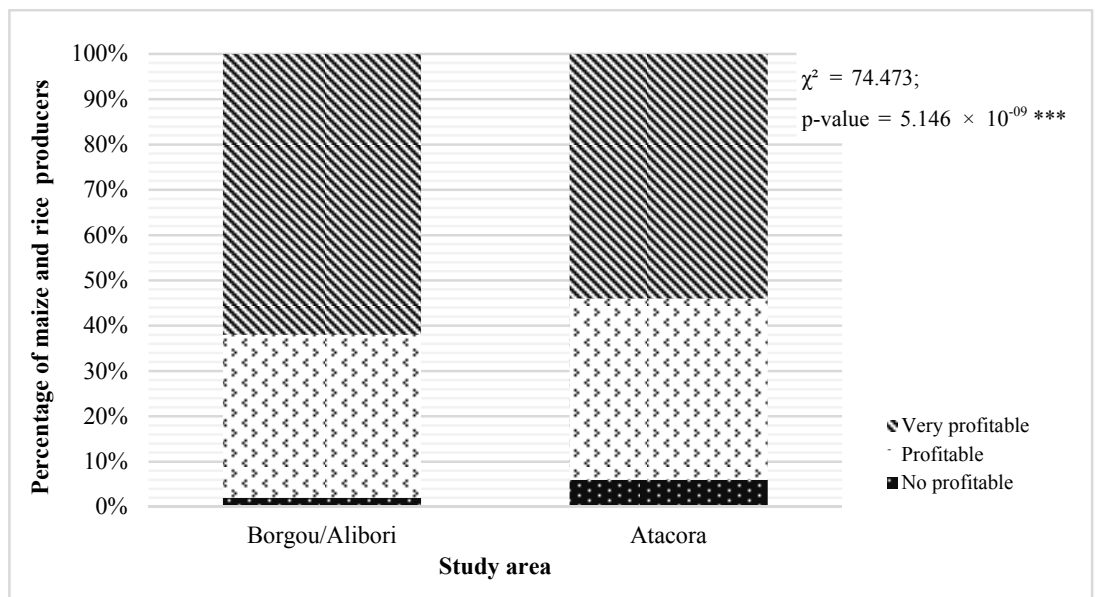

Figure 3. Perception of the profitability of the warrantage operation

Note. ${ }^{* * *}: \mathrm{p}<0.001$.

\subsection{Profitability of the Warrantage Operation}

The analysis of the profitability of the warrantage operation was measured by the calculation of the profit margin. Table 4 presents the results of the profitability calculation. It appears from reading this table that the warrantage transaction generates a positive profit margin. This margin was calculated for $1 \mathrm{~kg}$ of maize or rice sold. Thus, in the departments of Borgou and Alibori, the profit margin generated after the warrantage activity is $58.48 \mathrm{Fcfa} / \mathrm{kg}$ of maize against $57.08 \mathrm{Fcfa} / \mathrm{kg}$ for Atacora These profits margins represent respectively the rate of $41.98 \%$ and $32.91 \%$ of the sale price on destocking. The profit margin obtained for rice is $13.72 \mathrm{FCFA} / \mathrm{kg}$ which represent a rate of $10.29 \%$ of the sale price at destocking in the departments of Borgou and Alibori.

Table 4. Profit margin of the warrantage transaction

\begin{tabular}{|c|c|c|c|c|}
\hline \multirow{2}{*}{\multicolumn{2}{|c|}{ Designations }} & \multicolumn{2}{|c|}{ Borgou and Alibori } & \multirow{2}{*}{$\begin{array}{l}\text { Atacora } \\
\text { Maize }\end{array}$} \\
\hline & & Maize & Rice & \\
\hline \multirow{2}{*}{\multicolumn{2}{|c|}{ Destocked quantity $(\mathrm{Kg})$}} & Mean & & \\
\hline & & $8285(12046)$ & $8000(8845)$ & $5130(8930)$ \\
\hline \multicolumn{2}{|l|}{ Storage cost (FCFA/Kg) } & $3.02(2.72)$ & $3.75(2.08)$ & $1.52(0.59)$ \\
\hline \multicolumn{2}{|c|}{ Commission paid to the management committee (FCFA/Kg) } & $2.27(3.22)$ & $0.28(0.48)$ & $0.17(0.85)$ \\
\hline \multicolumn{2}{|l|}{ Interest paid (FCFA/Kg) } & $1.96(1.41)$ & $8.76(2.72)$ & $2.33(1.56)$ \\
\hline \multicolumn{2}{|l|}{ Total charges (FCFA/kg) } & $78.27(16.29)$ & $109.29(16.81)$ & $78.68(13.58)$ \\
\hline \multicolumn{2}{|l|}{ Selling price $(\mathrm{FCFA} / \mathrm{Kg})$} & $138.26(6.64)$ & $133.33(11.79)$ & $120.75(14.95)$ \\
\hline \multirow{2}{*}{ Margin (FCFA $/ \mathrm{Kg}$ ) based on estimated revenue } & No interest paid & $59.99(17.86)$ & $24.05(5.03)$ & $42.07(13.39)$ \\
\hline & With interest paid & $58.48(18.16)$ & $13.72(5.04)$ & $57.08(13.65)$ \\
\hline
\end{tabular}

Note. * ( ): Standard deviation. 


\subsection{Advantages, Weaknesses, Potentialities and Obstacles of the Warrantage Mechanism}

The advantages, weaknesses, potentialities and obstacles of the warrantage mechanism collected at the level of individual producers were analyzed, prioritized and the results were presented in Tables 5, 6, 7 and 8. Kendall performed at the level of each section showed that there is a significant difference between the various elements of advantages, weaknesses, opportunities and obstacles at the threshold of $1 \%$ overall and therefore indicates that there is a concordance in the classifications made by each of the producers participating or not participating in the process. Tables 5, 6, 7 and 8 were related the prioritization of the advantages, weaknesses, potentialities and obstacles of the warrantage mechanism. The classification of the advantages (Table 5) has shown that selling at a remunerative price, good conservation of stock, obtaining credit, improving income and easy access to fertilizers constitute the five main success factors noted by producers. As for weaknesses (Table 6), the classification made showed that the delay and insufficiency of the credit granted, the unavailability of products for processing, the non-remunerative sale price due to early or late destocking and the insufficiency of information and awareness and the absence of stores specific to producers, constitute the major weaknesses which slow down the implementation of the warrantage operation. Besides the advantages and weaknesses of the warrantage mechanism, there are potentials that would contribute to the success of the warrantage. Table 7 has shown that the existence of microfinance structures and the availability of producers to participate in the process represent the main potential of the warrantage mechanism. In addition to the potential, obstacles have been identified. At the end, Table 8 has shown that the absence of a drainage market and the absence of adequate stores for storage represent the main threats to the warrantage system in the two regions.

Table 5. Advantages of the warrantage mechanism

\begin{tabular}{lll}
\hline Advantages & Average rank & Rank \\
\hline Sale at a remunerative price & 4.9 & 1 \\
Good conservation of stocks & 5.48 & 2 \\
Obtaining credit & 5.5 & 3 \\
Improved revenues & 5.89 & 4 \\
Easy access to fertilizers & 5.98 & 5 \\
\hline W of Kendall & $0.074 * * *$ & \\
\hline
\end{tabular}

Note. ${ }^{* *}: \mathrm{p}<0.001$.

Table 6. Weaknesses of the warrantage mechanism

\begin{tabular}{lll}
\hline Weaknesses & Average rank & Rank \\
\hline Delay in setting up the loan granted & 3.59 & 1 \\
Non availability of products for treatment & 3.94 & 2 \\
Non-remunerative selling price due to early or late destocking & 3.96 & 3 \\
Lack of information and awareness & 3.97 & 4 \\
Lack of producers' own stores & 4.06 & 5 \\
W de Kendall & $0.023^{*}$ & \\
\hline
\end{tabular}

Note. $* \mathrm{p}<0.1$.

Table 7. Potentialities of the warrantage mechanism

\begin{tabular}{lll}
\hline Potentialities & Average rank & Rank \\
\hline Existence of microfinance structures & 1.64 & 1 \\
Availability of producers & 3.17 & 2 \\
Existence of adequate stores & 3.33 & 3 \\
Availability of warrantable products & 3.38 & 4 \\
Existence of sales market & 3.48 & 5 \\
\hline W of Kendall & $0.407 * *$ & \\
\hline
\end{tabular}

Note. ${ }^{* *}: \mathrm{p}<0.05$. 
Table 8. Obstacles of the warrantage mechanism

\begin{tabular}{lll}
\hline Obstacles & Average rank & Rank \\
\hline Lack of sales market & 2.69 & 1 \\
Lack of adequate store & 2.92 & 2 \\
Weak adhesion of producers & 2.95 & 3 \\
Non availability of inputs (fertilizer) & 3.11 & 4 \\
Climatic hazards (lack of rain) & 3.32 & 5 \\
W of Kendall & $0.039^{*}$ & \\
\hline
\end{tabular}

Note. ${ }^{*}: \mathrm{p}<\overline{0.1 \text {. }}$

\section{Discussions}

The socio-economic assessment of the warrantage mechanism at the level of producers of maize and rice in North Benin revealed on the one hand that producers have developed this operation more in agriculture and trade in agricultural products. The study revealed that the practice of the warrantage mechanism is considered very profitable by the producers but has generated a positive and high profit margin in terms of corn and rice crops. The warrantage system which allows small farmers to postpone the sale of their goods, which allows them to take advantage of large seasonal variations in prices for these products and to obtain substantial liquidity at the start of the harvest (Beaure, 2007a). According to Coulter (1998) and Somda et al. (2010), warrantage favors farmers, to maximize their profits when the price of products is at the highest on the market. Warrantage is a simple solution to the problem of selling off production just after harvest. The warrantage mechanism ensures the transparency of the sale price at the time of the settlement of the stored products. The selling price is a key variable in the profitability of the warrantage operation for producers. One of the effects of warrantage is collaboration between farmer groups and the warehouseman to establish prices based on the market value of the product. Producers are thus regularly informed of price developments, and help set prices instead of suffering them (Wampfler, 2008; Egah, 2014). Beyond this financial advantage, the producers see especially in this device a means of keeping food stocks for the family without making punctures there to meet their monetary needs because the keys of the storage stores are held by the structure finance and farmer organization (Coulter et al., 1998). The practice of warrantage creates a winning partnership between producers, microfinance institutions and farmers' organizations (Somda, 2010). According to a study carried out in Burkina Faso (Malnoury, 2011), 68 households put 38 tonnes of millet in stock and received 3 million FCFA in credit (nearly 70 euros per household) with an annual interest rate of $12 \%$. This rate, much lower than that imposed on family farmers outside the system, is comparable to that in force in the banking system, almost inaccessible to small producers. Producers also benefited from reliable storage and a maximum level of conservation. More than $80 \%$ of these cereals, of recognized quality, were sold to processors in Dakar, at a rate of 165 FCFA per kg, while the valuation price at storage was 125 FCFA. This has enabled producers on the one hand to achieve a high profit margin and on the other hand the microfinance institution and the farmers' organization to fully recover the loans granted and interest. In Nigeria, for example, warrantage systems funded by non-government organizations (NGOs) and farmers' producer organizations (POs) allow farmers to increase selling prices in the ranges of 55\%, 81\% and 92\% for rice, cowpea and soybeans, respectively (Wampfler et al., 2007; Othman et al., 2009; Höllinger, 2015). The loans obtained by warrantage are also used to finance agricultural activities, income-generating activities (IGAs) and other social needs (Othman et al., 2009). In Niger, through credit inputs based on warrantage, farmers could record gains of $19 \%$ to $113 \%$ on capital investments over six months (Coulter, 2009). As a result, warrantage provides farmers with benefits such as access to agricultural inputs and at seasonal prices (Duffau, 2011). Nevertheless, warrantage is a system which sometimes favors the speculative behavior of farmers, who try to maximize their profits while waiting for the price of products to be high to sell. When this point is reached, the flow of goods dumped on the market almost immediately drops the price. This can leave producers with more than half of their stock when prices are lowest (Malnoury, 2011; Jovičić, 2014).

The study on socio-economic evaluation of the warrantage mechanism also revealed that the warrantage mechanism presents successes which are: selling at a remunerative price, good conservation of stocks, obtaining credits and improving incomes at the producer level. For (Beaure, 2007a; Konlambigue, 2007), warrantage activity is beneficial because it allows access to credit at a low interest rate, guarantees food self-sufficiency and access to fertilizers for agricultural production (Chetaille et al., 2011). Indeed, producers can convert their savings by "buying back" their products from the warehouse for personal consumption during the off-peak season, when food is expensive. The warrantage credit provides producers with an immediate guarantee to 
guarantee a loan (Wampfler, 2003). This type of high market value guarantee is attractive to microfinance institutions that rely on social pressure to obtain repayments. Unlike land holdings or other forms of collateral, the collateral provided by the stock (agricultural products) is liquid. It can be converted into cash at a bank or in the market. This represents an interest for the microfinance institution, which may encounter certain difficulties in doing so reimburse by the farmer (Boubacar, 2007; Coulter, 2009). The warrantage allowed the capacity building of the producers, the rapprochement and the contact of the agents with the producers. Some agents have made great efforts to help producers, especially for the disposal of stocks at a remunerative price (Augères, 2007; Tabo et al., 2011). The study also revealed that the mechanism of the warrantage presents some failures which are: the delay in the implementation of the granted credit and the unavailability of the products for the treatment of the stored products. Producers, whatever their category, consider that the amount of credit granted according to the stock is not enough and does not allow them to meet the needs for which they took the credit. Also, they believe that the granting of credit is late; which does not allow the money to be used for other farming operations. After these two failure factors, the unavailability of treatment products, insufficient information and awareness were revealed by the producers. According to (Attahirou, 2007; Wampfler, 2008), poor storage techniques (or insufficient drying or conservation devices for agricultural products) constitute failures of the mechanism of the warrantage system. In fact, in rural areas, where storage technologies are lacking or too expensive, deterioration, harmful insects and lower quality are all risks for the products stored. The warrantage mechanism involves certain additional costs for producers. These are the high costs of transporting harvested products to the bonded warehouse (AFD, 2011). These charges may deter farmers from storing their produce. The socio-economic evaluation of the warrantage mechanism revealed that this mechanism has potentials which have contributed to its success. It is about the existence of micro-finance structures and the availability of producers to participate in the process. Certain obstacles were identified during the study and constitute threats to the proper execution of the warrantage. They concern the absence of a market for the sale of stored products and the absence of stores suitable for storage. According to (Malnoury, 2011), warrantage generates an economy of scale in the sense that the cost of administration and supervision of the credit-warrantage system decreases with increasing scale. The more warehouses available, the lower the cost of monitoring the system. The warrantage mechanism is often favored by a permanent effort of training and information (USAID, 2010; FAO, 2010b; Le Magadoux, 2013). A warrantage system cannot function efficiently and benefit from a satisfactory penetration rate, without accompanying measures (Traore, 2016). Awareness-raising work is done at two levels: on the one hand, strengthening the technical skills of the intermediary structures in charge of distributing products (microfinance institutions, inventory managers) and, on the other hand, farmers on the overall functioning of the system (Ndimubandi, 2010; Garido \& Sanchez, 2015).

\section{Conclusion}

The study on socio-economic evaluation of the warrantage mechanism in North Benin among maize and rice producers revealed that the warrantage mechanism is more realized in agriculture and trade. This study revealed that the completion of the warrantage transaction generated a positive and high profit margin for the maize and rice crops. Analysis of the successes, failures, potentials and obstacles of the warrantage mechanism revealed that selling at a remunerative price, good conservation of stocks, obtaining credits and improving incomes at producer level constitute its successes. The delay in setting up the credit granted and the unavailability of products for the treatment of stored products were the failures. The existence of micro-finance structures and the availability of producers to participate in the process were the potentials of the warrantage mechanism, while the non-existence of a market for the sale of stored products and the absence of stores suitable for storage constitute these obstacles.

Although the results obtained are satisfactory, it is essential to control and orient the warrantage to prevent the operation and all the associated advantages from being monopolized by large producers and traders. To do this, it is recommended to:

- develop eligibility criteria for participation in warrantage in order to clearly identify the categories of producers who genuinely need it;

- rely on producer organizations and not producer groups for the extension phase;

- diligently set up credits after the collection and storage of warranted products in order to reduce waiting times for producers;

- strengthen the managerial capacities of the members of the management committees for better management;

- harmonize with microfinance institutions, the interest rates charged as well as the various fees levied when setting up and recovering loans; 
- establish a partnership with the managers of agricultural input stores to facilitate the timely implementation of agricultural inputs.

\section{References}

AFD. (2011). Document de travail AFD: Focus sur l'assurance récolte indicielle et le warrantage (p. 86). Retrieved from http://www.gret.org/wp-content/uploads/113-document-travail.pdf

AFDI. (2007). Le warrantage ou crédit stockage: Un moyen pour les paysans de mieux valoriser leurs produits et une sécurisation du financement rural. Rapport d'étude (p. 17).

Antonaci, L., Demeke, M., \& Soumare, M. S. (2013). Integrating Risk Management Tools and Policies into CAADP: Options and Challenges (p. 21). FAO/NEPAD.

Attahirou, G. B. (2007). Expérience de commercialisation de produits agricoles par le mécanisme du warrantage au sein de la fédération $S A$ 'A (p. 18). Contribution de la Fédération des Unions de Producteurs de Souchet du Niger (FUPSN-SA'A), Inter-réseaux Niger. Retrieved from http://www.inter-reseaux.org/ IMG/pdf/Niger_Warrantage_FUPSN_Saa_2007.pdf

Augères, C. B. (2007). Le warrantage ou crédit stockage: Un moyen pour les paysans de mieux valoriser leurs produits et une sécurisation du financement rural (p. 15). Forum régional Bamako, Inter-réseaux Développement Rural-CTA.

Beaure d'Augeres, C. (2007a). Le warrantage ou crédit de stockage: Un moyen pour les paysans de mieux valoriser leurs produits et une sécurisation du financement rural (p. 16). Inter-réseaux/CTA/AFDI.

Boubacar, S. (2007). Warrantage in Niger (p. 14). Microfinance for Agriculture in Developing Countries Conference, FAO. Retrieved from http://www.fondation-farm.org/zoe/doc/a2_boubacar_fao_ang_ppt.pdf

Bouchitté, A., \& Dardel, S. (2012). Marches agricoles et petits producteurs: Instruments d'accès et gestion des risques. Note d'information (p. 46).

Chetaille, A., Duffau, A., Horréard, G., Lagandré, D., Oggeri, B., \& Rozenkopf, I. (2011). Gestion des risques agricoles par les petits producteurs: Focus sur l'assurance récolte indicielle et le warrantage (p. 86). Agence Française de Développement. Retrieved from http://www.microfinancegateway.org/sites/default/files/mfgfr-etudes-de-cas-gestion-des-risques-agricoles-par-les-petits-producteurs-05-2011.pdf

Codjo, V., Zannou, A., \& Biou, G. (2018). Baisse des ressources halieutiques du lac Toho au Sud du Bénin: Perceptions des pêcheurs et de l'efficacité des pratiques de gestion et stratégies d'adaptation. Tropicultura, 36(4), 713-721. https://popups.uliege.be/2295-8010/index.php?id=439\&file=1

Coulter, J., \& Mahamadou, S. (2009). Revue du warrantage paysan au Niger (p. 59). Agence Française de Développement (AFD). Retrieved from http://www.fao.org/3/a-as606f.pdf.

Coulter, J., \& Norvell, N. (1998). The Role of warrantage in Africa: Lessons from Four Continents. Actes de la conférence sur le développement de la CNUCED à Lyon (p. 56). Genève: UNCTAD.

Duffau, A., Lagandré, D., Chetaille, A., Rozenkopf, I., \& Horréard, G. (2011). Assurance indicielle et warrantage, quel intérêt pour les petits agriculteurs? Coll. Études et Travaux, 28, 44.

Egah, J., Baco, M. N., Moumouni, M. I., Akponikpe, P. B. I., Yegbemey, R. N., \& Toussou, R. C. (2014). Performance of institutional innovation: The case of maize-related warrantage in Benin, West Africa. International Journal of Agriculture Innovations and Research, 3(2), 473-479. Retrieved from http://www.ijair.org/administrator/components/com_jresearch/files/publications/IJAIR_936_Final.pdf

FAO. (2010a). Le warrantage dans l'Union Cigaba de Konkorindo, Région de Dosso-Niger. Projet Capitalisation (p. 4). Retrieved from http://doc.capitalisation-bp.net/FAOCapitalisation_FicheKonkorindo Niger.pdf

FAO. (2010b). Etude de cas sur l'expérience de warrantage dans le sud ouest du Burkina Faso. Atelier régional de formation sur le renforcement des capacités des organisations de producteurs à répondre à l'évolution de l'agriculture moderne (p. 28). FAO/GRET/Union Européenne. Retrieved from http://biblio.capitalisation -bp.net/warrantage/EtudeWarrantageSOBurkina_FAO_GRET_UE2010.PDF

FAO. (2011). Manuel de formation sur le warrantage au Niger. Retrieved from http://www.fao.org/3/a-as613f.pdf

Fraval, P. (2000). Eléments pour l'analyse économique des filières agricoles en Afrique sub-saharienne. Bureau des politiques agricoles et de la sécurité alimentaire (p. 100). DCT/EPS. 
Garrido, E. S., \& Sanchez, I. S. (2015). Warrantage paysan au Burkina Faso. Burkina Faso: OXFAM. Retrieved from https://www.oxfam.org/sites/www.oxfam.org/files/file_attachments/rr-warrantage-burkina-faso-14101 5-fr.pdf

Gouillat, E. (2014). Le warrantage, un système au service du financement des producteurs agricoles. Portail de la microfinance (p. 23).

Höllinger, F., Rutten, L., \& Kiriakov, K. (2015). The use of warehouse receipt finance in agriculture in transition countries. Retrieved from https://www.agrifinfacility.org/sites/agrifinfacility.org/files/vberisha/51/TechSum 6 _UseOfWarehouseReceipt_1520066_Web.pdf

Jovičić, D., Jeremić, L., Milićević, L., \& Zeremski, A. (2014). Warehouse receipts functioning to reduce market risk. Economics of Agriculture, 2(61), 347-365. https://doi.org/10.5937/ekoPolj1402347J

Kendall, M. G. (1955). Rank correlation methods (2nd ed., p. 19). London Griffin and Co.

Konlambigue, A. (2007). Financing agricultural inputs in Northern Togo through an inventory credit system: An economic analysis of institutional response. African Association of Agricultural Economists (AAAE). Retrieved from http://purl.umn.edu/52100

Le Magadoux, A., Mahamane, A., Déla Sida, F., \& Van der Elstraeten, A. (2013). Gestion des intrants et genre: Le warrantage équitable appliqué par l'union Cigaba (p. 27). Niger. Retrieved from http://www.fao.org/ documents/card/fr/c/b477b92a-bd58-5e0f-985c-daa04726cac2

Lothoré, A., \& Delmas, P. (2010). Accès au marché et commercialisation de produits agricoles/Valorisation d'initiatives de producteurs. Inter-réseaux Développement Rural (p. 178).

Madulu, R. B. (2011). Improving access to credit for paddy farmers through warehouse receipt-based agricultural marketing system in Tanzania. African Crop Science Conference, 10, 37-39. Retrieved from http://www.cabi.org/cabdirect/FullTextPDF/2013/20133200276.pdf

Malnoury, G. (2011). Analyse du système de warrantage et de son impact sur les ménages ruraux au Burkina Faso: Provinces du Tuy et du Ioba. Rapport d'étude (p. 95).

Ndimubandi, J. (2010). Evaluation du projet de facilitation sur le warrantage. Retrieved from http:/www.capad.info/IMG/pdf/RAPPORT-FINAL-WARRANTAGE-1-2.pdf

Othman, M. K., Bolorunduro, P., Ibrahim, A., \& Dayot, B. (2009). Inventory Credit as Micro-Finance Tool for Community Development: A Pilot Study of Selected Farmers' Organizationsin Two States of Northern Nigeria. Savanah Journal of Agriculture, 4, 30-39.

Pender, J., Abdoulaye, T., Ndjeunga, J., Gerard, B., \& Kato, E. (2008). Impacts of inventory credit, input supply shops, and fertilizer microdosing in the drylands of Niger (p. 88). International Food Policy Research Institute. Retrieved from http://ageconsearch.umn.edu/bitstream/42328/2/ifpridp00763.pdf

Somda, M.-D. (2010). Etude de cas sur l'expérience de Warrantage dans la région du Sud-Ouest du Burkina Faso (p. 28). GRET/FAO.

Tabo, R., Bationo, A., Amadou, B., Marchal, D., Lompo, F., Gandah, M., ... Koala, S. (2011). Fertilizer microdosing and "warrantage" or inventory credit system to improve food security and farmers" income in West Africa. In A. Bationo, B. Waswa, J. M. Okeyo, F. Maina, \& J. M. Kihara (Eds.), Innovations as Key to the Green Revolution in Africa (pp. 113-121). http://doi.org/10.1007/978-90-481-2543-2_10

Tabo, R., Konlambigue, A. M., \& Maatman, A. (2006). Project on fertilizer micro-dosing for small farmer prosperity in the Sahel: Training workshop on large-scale transfer (scaling-up) of fertilizer micro-dosing technology. Agroecosystems Report No. 22, ICRISAT, Niamey (p. 24). USAID TARGET.

Traore, A. (2016). Résultats, évidences et leçons apprises: Programme FASO warantage. CRS. Retrieved from http://sarel.245elmp13.blackmesh.com/sites/default/files/WarrantagePresentation-Forum-Collab-Coord-RIS E-Burkina-Faso(002)

USAID. (2010). Etude de faisabilité sur le développement du crédit de stockage (warrantage) (p. 123). USAID/Poly Conseils.

Vermeylen, B. (2007). Le Warrantage: Introduction au concept (p. 5). DTF PDSA-BA, Caritas International et CADEV Niger

Wampfler, B. (2003). Sécuriser le crédit aux organisations paysannes par le warrantage. Note d'Information (p. $10)$. 
Wampfler, B. (2008). Le développement du Warrantage au Niger (p. 8). Communication du projet Intrants FAO au Colloque FARM, Paris.

Wampfler, B., Bouquet, E., \& Ralison, E. (2007). Expérience de crédit-bail du réseau CECAM de Madagascar (p. 25).

Yamane, T. (1967). Statistics: An Introductory Analysis (2nd ed.). New York: Harper and Row.

\section{Copyrights}

Copyright for this article is retained by the author(s), with first publication rights granted to the journal.

This is an open-access article distributed under the terms and conditions of the Creative Commons Attribution license (http://creativecommons.org/licenses/by/4.0/). 